\title{
Chapter 2 \\ Why Are Collective Actions Needed \\ in Europe: Small Claims Are Not \\ Reasonably Enforced in Practice \\ and Collective Actions Ensure Effective \\ Access to Justice
}

It is probably very easy to agree with the tenet that "[r]ights which cannot be enforced in practice are worthless." ${ }^{1}$ Small claims face hurdles that may prevent individual enforcement and lead to sub-optimal litigation. ${ }^{2}$ While the practical nonenforceabilty of small value claims is often conceived as a question of effectiveness, ${ }^{3}$ it also has serious human rights and rule of law implications. ${ }^{4}$

Article 47 of the EU Charter of Fundamental Rights, with reference to legal aid, treats access to justice as part of the right to an effective remedy and to a fair trial. ${ }^{5}$ Access to justice is also part of the requirement of rule of law, one of the core values of the EU enshrined in Article 2 TEU. ${ }^{6}$

Furthermore, Member States, due to the principle of loyalty, are obliged to ensure the effective enforcement of EU law. According to Article 4(4) TEU, "Member States shall take any appropriate measure, general or particular, to ensure fulfilment of the obligations arising out of the Treaties or resulting from the acts of the institutions of the Union." According to the CJEU's judicial practice, Member States' enforcement of EU law is subject to two general requirements: the principle of equivalence and the principle of effectiveness. National rules governing the enforcement of EU law may not be less favorable than those governing similar domestic actions

\footnotetext{
${ }^{1}$ European Commission Staff Working Document Public Consultation: Towards a coherent European approach to collective redress, SEC (2011) 173 final, para 1.1.

${ }^{2}$ For a detailed elaboration of the analysis set forth in this section, see Nagy (2013: 469-498).

${ }^{3}$ See Neumann and Magnusson (2011: 154-155), Juska (2014), Bosters (2017: 17).

${ }^{4}$ For an overview of the intersection between collective actions and human rights, in particular access to justice, see Hodges (2008: 187-192), Lange (2011: 95-106), Neumann and Magnusson (2011: 151-152), Wrbka et al. (2012), Azar-Baud (2012: 15, 17-18), Vanikiotisa (2014: 1643-1644), Mulheron (2014: 52-57).

5 "Legal aid shall be made available to those who lack sufficient resources in so far as such aid is necessary to ensure effective access to justice."

${ }^{6}$ European Union Agency for Fundamental Rights and Council of Europe (2016: 16).
} 
(principle of equivalence) and they may not make the enforcement of EU law practically impossible or excessively difficult. ${ }^{7}$

Not surprisingly, the Commission's Recommendation on Collective Redress defines collective actions as a means to "facilitate access to justice in relation to violations of rights under Union law" and to reinforce the effectiveness of EU law. ${ }^{8}$

The purpose of this Recommendation is to facilitate access to justice, stop illegal practices and enable injured parties to obtain compensation in mass harm situations caused by violations of rights granted under Union law, while ensuring appropriate procedural safeguards to avoid abusive litigation. ${ }^{9}$

The Recommendation is based on the premise that collective actions enhance both the effectiveness of the law (through stopping and deterring unlawful practices) and the chance to obtain a real legal remedy (compensation).

These measures are intended to prevent and stop unlawful practices as well as to ensure that compensation can be obtained for the detriment caused in mass harm situations. The possibility of joining claims and pursuing them collectively may constitute a better means of access to justice, in particular when the cost of individual actions would deter the harmed individuals from going to court. ${ }^{10}$

This chapter demonstrates how and why collective actions make the enforcement of small value claims a reality, thus ensuring access to justice and effectiveness of the law. It addresses three questions: why is the practical enforcement of small value claims difficult or even unfeasible, how do class actions make it work and why can class actions not become a reality without legislative intervention?

In case of small-value claims it may be economically unreasonable to litigate (the expected costs may be higher than the expected value) even in well-founded cases of merit. First, non-recoverable legal costs may deter litigation. Although in Europe legal costs are, in principle and with some restrictions, borne by the losing party, the winning party cannot shift the legal costs in full. Second, the costs of the preliminary legal assessment may also dissuade the plaintiff. Third, in the context of small claims, the value at stake is small and legal costs are, in comparison to the claim's value, very high - here, a relatively trivial probability of failure may make the balance of litigation negative. The higher the legal costs are in relation to the claim's value, the better this risk crops out.

Collective actions have certain advantages that make the enforcement of small claims possible in cases where numerous persons are damaged by the same illegal act. Although damages are small for each individual (which may make litigation unreasonable), collective damages (the sum of various individuals' damages) are high. The merit of collective actions can be attributed to two virtues: economies of

\footnotetext{
${ }^{7}$ See e.g. Case C-261/95 Palmisani [1997] ECR I-4025, para 27; Case C-453/99 Courage and Crehan [2001] ECR I-6297, para 29; Joined Cases C-295/04 to C-298/04 Manfredi [2006] ECR I-06619, para 62.

${ }^{8}$ Recitals (1) \& (10).

${ }^{9}$ Para 1.

${ }^{10}$ Recital (9).
} 
scale $^{11}$ and tackling external economic effects (externalities). These are due to the fact that the enforcement of individual small claims may have significant common $\operatorname{costs}^{12}$ and individual litigation may entail positive external effects (externalities), conferring advantages on other class members they did not pay for.

Although group members could avail themselves of various traditional legal tools (joinder of parties, ${ }^{13}$ assignment of claims to an entity founded by group members) to organize the group, ${ }^{14}$ these are, at leat in case of small claims, not effective substitutes of collective actions owing to the costs of group organization. These costs may be very high, in some cases even prohibitive, ${ }^{15}$ and traditional legal tools are not tailored to the needs of collective litigation, thus increasing the costs of group management. ${ }^{16}$

For the purpose of the present volume, small claims are defined as civil claims where the litigation's expected value is less than its expected costs (out-of-pocket expenses and related inconvenience). At this point, for the sake of simplicity, it is disregarded that the same value (pay-out) may have different utilities for people with different assets and personal preferences (expected utility); likewise, it is assumed that the decision-maker is risk-neutral. When calculating the expected value, it is to be taken into account that litigation is burdened by dubiety and the outcome, in terms of practice, cannot be predicted with full certainty. Hence, a rational decisionmaker makes his choice whether to enforce the claim or not on the basis of the balance of litigation's expected value (which stands for the revenue if carrying the day multiplied by the probability that the plaintiff wins the law-suit) and expected costs. If the expected value exceeds the expected costs, it is reasonable to sue.

\subsection{What Are the Hurdles Faced by Small Claims in Europe}

In Europe, there are essentially three factors that may discourage potential plaintiffs from enforcing their claims: the "loser pays" principle does not work to the full (there are some legally unrecoverable expenses and there are some expenses that cannot be proved), the costs of the preliminary legal assessment and the risk of losing the lawsuit (legal and factual uncertainties and dubiety related to the law-suit's outcome; i.e. the risk of bearing the legal costs).

\footnotetext{
${ }^{11}$ See e.g. Ulen $(2011: 185,187)$.

${ }^{12}$ See Bone (2003: 261-265).

${ }^{13}$ Nagy (2011: 163), Geiger (2015: 32-73).

${ }^{14}$ See Commission Report on the implementation of the Commission Recommendation of 11 June 2013 on common principles for injunctive and compensatory collective redress mechanisms in the Member States concerning violations of rights granted under Union law (2013/396/EU), $\operatorname{COM}(2018) 40$ final, p 2 ("In the Member States where (...) [collective redress mechanisms] do not formally exist there appears to be an increasing tendency of claimants attempting to seek collective redress through the use of different legal vehicles like the joinder of cases or the assignment of claims.").

${ }^{15}$ Ulen (2011: 185, 191).

${ }^{16}$ For a detailed analysis, see Nagy (2013: 469, 478-479).
} 
First, legal costs may deter litigation. As in Europe legal costs are, in principle and with some restrictions, borne by the losing party, the advancing of legal costs should, theoretically, not impede the enforcement of well-founded claims, if assuming that there is $100 \%$ probability that the plaintiff wins the law-suit. Nevertheless, in practice, this is seldom the case. The winning party cannot shift the legal costs in full onto the losing party: the proof and documentation of the legal costs may be difficult; furthermore, the law may restrict the amount of the attorney's fees that can be shifted on the losing party; finally, the preliminary legal assessment, examining the probability of plaintiff success, occurs in a stage where the plaintiff has little information about his chances.

Litigation gives rise to some practically unrecoverable expenses; these are to be borne by the plaintiff irrespective of whether he carries the day or not (de facto non-shiftable costs). There are certain costs that may be legally shifted but cannot be proved. Since in this regard the burden of proof rests on the plaintiff, he inevitably faces some risk of proof emerging from factual uncertainties. It is not realistic to assume that the party can prove all his costs before the court, since smaller expenses may not be certifiable. In the context of small claims even relatively negligible expenses may be significant.

Furthermore, there are certain costs that legally cannot be shifted onto the losing party (de jure non-shiftable costs): e.g. inconveniences related to litigation, the time the plaintiff spends on the law-suit. One subset of this category is capped costs. For instance, in certain European countries the law establishes the maximum amount of attorney's fees that can be shifted on the losing party, while the market price of attorney services may be much higher. ${ }^{17}$ The usual perception is that the price of attorney services is unregulated and the legally determined schedule of attorney's fees sets out lower fees than the market price. In this case the law, due to the schedule of attorney's fees, enables the plaintiff to shift his attorney's fees only in part. In other civil-law systems, there is no pre-determined schedule of attorney's fees that can be shifted on the losing party but the law authorizes the court to control the fees and it may reduce the amount that can be shifted, if the attorney's fees are not proportionate to the work done or the value of the claim. ${ }^{18}$ Accordingly, the plaintiff faces some uncertainty as to whether the attorney's fees will be shifted at the end of the day.

Second, the expenses of the preliminary legal assessment may also discourage the plaintiff. These consist of the information costs of learning whether the plaintiff has a "good case" and how high the risk of losing the law-suit is. Here, the legal counsel assesses the fact pattern and gives advice as to whether to sue and what the potential outcomes of the law-suit are. Although these are costs that emerge in the litigation process broadly speaking and, as such, the winning party may be able to shift them onto the loser, it should not be disregarded that there is a good deal of information shortage in such scenarios. Laymen themselves may not be able to do the preliminary

\footnotetext{
${ }^{17}$ See the case of Germany: Rechtsanwaltsvergütungsgesetz vom 5. Mai 2004 (BGB1. I S. 718, 788), zuletzt geändert durch Artikel 3 des Gesetzes vom 8. Juli 2006 (BGBl. I S. 1426). On the German system, see Wagner (2009: 367).

${ }^{18}$ See the case of Hungary: Regulation 32/2003 (VIII. 22.) of the Minister of Justice.
} 
legal assessment of their chances in a law-suit and, hence, when they are asking for a legal advice they have to take into account that they may have to pay the costs of the preliminary legal assessment even in a case when there is no reason to sue. Thus, in case of small claims, the expenses related to the preliminary legal assessment may have a discouraging effect because the party has to incur costs without knowing the probability of whether they will be recovered or not.

Third, litigation inevitably involves some risk. As a matter of practice, almost all law-suits have immanent risks; a claim may be a good case but seldom a perfect one, let alone the risks emerging from enforcement issues and the defendant's possible insolvency. Accordingly, the party has to take into account that there is a certain risk (even if a negligible one) that he loses the case and, hence, his legal costs would not be recovered and he has to reimburse the opposing party for his expenses.

As in case of small claims the value at stake is small, a relatively trivial probability of failure may make the balance of litigation negative. Assume that the plaintiff suffered $€ 100$ loss due to a bank's overcharge and the legal costs would be $€$ 10,000 altogether; it is also assumed that the claim is fully legitimate but the plaintiff considers that there is a $1 \%$ chance that he would lose the case; finally, for the sake of simplicity, it is also assumed that all legal costs are borne by the losing party (no restrictions apply, neither legal, nor factual). In this case, the expected value of the law-suit is $€ 100 \times 0.99=€ 99$, while the expected costs are $€ 10,000 \times 0.01=$ $€ 100$. As a corollary, the balance of litigation is negative ( $€ 99-€ 100=€-1$ ) and it is not reasonable to sue. Accordingly, a negligible amount of risk may hinder the plaintiff from the law-suit, if legal costs are high in relation to the claim's value. The higher the legal costs are in relation to the claim's value, the better this risk crops out.

It needs to be added that, as a matter of practice, litigation usually involves some risk, even if a negligible one. Furthermore, there is always a risk that even though the court decides for the plaintiff, the enforcement of the judgment fails for some reason (e.g. the judgment debtor becomes bankrupt).

The consequence of the above is that in matters where numerous victims suffer individually small damages they are not seeking recovery on an individual basis and the only legal tool that, in terms of practice, remains at their disposal is public enforcement, e.g. administrative law, criminal law. Nonetheless, public enforcement normally does not imply private recovery ${ }^{19}$ : no recovery accrues to the victim from the criminal or administrative sanction imposed on the person committing the mischief. ${ }^{20}$

Accordingly, the conclusion may be drawn that in case of small claims the balance of the expected value and the expected costs may be negative also in cases that should be worth being brought before court, i.e. in cases that have a robust chance of success.

\footnotetext{
${ }^{19}$ For an exception to this general tenet, see Nagy (2012) (Demonstrating how the Hungarian Competition Office uses commitment procedures to further remedies under private law.).

${ }^{20}$ Contra Wagner (2011: 79) (Arguing that in case of scattered loss (small claims), the function of collective redress is deterrence.); see also Gilles and Friedman (2006: 105) (Arguing that the purpose of US consumer class actions is not to ensure compensation; instead, its sole purpose is deterrence.).
} 


\subsection{How Do Collective Actions Overcome the Above Hurdles and Why Are They Efficient?}

In the following, it is demonstrated that collective actions have certain merits that enable the enforcement of small claims in matters where numerous persons suffer loss due to the same mischief (individual loss is small and, hence, as a matter of practice, hardly enforceable, while the sum of the individual losses is high). The two main reasons of this virtue are economies of scale $^{21}$ and tackling the problem of external economic effects (externalities).

Collective litigation may lead to economies of scale. There are common costs between the claims and their joint enforcement may give rise to economies of scale and help avoiding externalities that individual litigation may entail ${ }^{22}$; of course these merits may be present not only in respect of small claims.

In related matters sharing common factual and legal issues, litigation costs are usually not directly proportionate to the number of the parties (plaintiffs). If the claims are tried in one action, witnesses have to testify only once and, similarly, liability is to be deliberated only once. ${ }^{23}$ Accordingly, if the attorney's workload is $10 \mathrm{~h}$ in relation to one client, this may, in case of 100 clients, be 100,200 or $300 \mathrm{~h}$ but not $1000 \mathrm{~h}$. A substantial part of the legal costs, including attorney's fees, may be fixed costs, i.e. they emerge irrespective of the number of the parties, while the rest is made up of variable costs, the volume of which depends on the number of the parties. There are certain issues whose analysis is independent of the number of the parties, while some other (factual and legal) issues are individual and cannot be shared. The ratio between the fixed and variable costs depends on the circumstances; nevertheless, it may be reasonably concluded that if the detriment suffered by the victims is due to the same cause, common (fixed) costs are likely to exist and if the fixed costs are substantial in relation to individual costs, collective litigation may be cost-effective.

Assume that there are 10 victims, each of them suffered damages in value of $€$ 1000 and the costs of individual litigation are $€ 750$ for the plaintiff and the defendant, respectively, $€ 500$ of which is fixed costs (at this point court fees, inflation and interest on overdue payments are disregarded). Furthermore, assume that the plaintiff has $50 \%$ chance to win the law-suit because this is a case of first impression raising legal questions that have not been tried before. In case of individual litigation, the balance of the expected value and the expected costs is the following: the expected value is $€ 500$ ( $€ 1000 \times 0.5)$, while the expected costs are $€ 750$ (since the "loser pays" principle applies, there is $50 \%$ chance that the plaintiff has to sustain the legal costs of both parties: $[2 \times € 750] \times 0.5$ ), assuming that legal costs can be perfectly calculated and shifted. Accordingly, the balance is negative $(€ 500-€ 750=€-$ 250) and it is not reasonable to sue.

\footnotetext{
${ }^{21}$ See e.g. Ulen (2011: 185, 187).

${ }^{22}$ See Bone (2003: 261-265).

${ }^{23}$ Ulen (2011: 187).
} 
Nonetheless, the balance is positive in case of collective litigation, provided certain costs can be shared. ${ }^{24}$ If all the 10 victims sue jointly, legal costs do not increase considerably. The costs on the plaintiffs' side are $€ 500$ common fixed costs and $€$ 250 individual variable costs multiplied by the number of group members $(€ 250 \times$ $10=€ 2500$ ); altogether, this is $€ 3000$. For the sake of simplicity, assume that the legal costs on the defendant's side do not change: $€ 750$. As a corollary, the total sum of the legal costs is $€ 3750$ and the expected costs are $€ 3750 \times 0.5=€ 1875$. On the other hand, the expected value decuples: $€ 1000 \times 0.5 \times 10=€ 5000$. Under such circumstances, it is reasonable to sue, since the balance of the expected value and the expected costs is positive ( $€ 5000-€ 1875=€ 3125)$.

This calculation assumes linear variable costs (no economies of scale due to variable costs); however, part of the variable costs may be degressive, making the total cost of the joint production of collective action on the plaintiffs' side less than $€ 3000$. For example, $€ 100$ may be linear, resulting in costs of $€ 1000$, while $€ 150$ of the variable costs may be degressive and increase not 10 times but only 7 times, so the total costs would amount to $€ 500+€ 1000+€ 1050=€ 2550$. Under such circumstances, it is even more reasonable to sue. The legal costs on the defendant's side do not change: $€ 750$. The total sum of legal costs is $€ 3300$, hence, the expected costs are $€ 3300 \times 0.5=€ 1650$. The expected value remains unchanged: $€ 1000$ $\times 0.5 \times 10=5000$ EUR. Under such circumstances, it is reasonable to sue, since the balance of the expected value and the expected costs is positive (€5000-€ $1650=€ 3350)$.

Another problem of individual enforcement of similar or identical claims emerging from the same cause is that individual litigation may entail significant positive externalities on fellow-sufferers. The litigation's "expected cost - expected value" balance may be negative on individual level but positive on group (or social) level. Since the positive external economic effect conferred on other group members is not internalized by the individual litigator, this may lead to suboptimal enforcement. This happens in test cases, which could be regarded as an alternative to collective actions. Here, one of the group members, as a pioneer, institutes an individual action in a matter that involves a question (or several questions) relevant for all group members. Once the question becomes judicially settled in the test case, this entails a positive externality on all other group members suing afterwards: since the court answers one of the crucial questions in the test case, the litigation risks of other group members decrease. Unfortunately, test cases are not an effective substitute of collective litigation. One of the reasons is that they may lead to free-riding: nonactive group members free-ride on the efforts of the member initiating the test case. Collective actions may tackle the positive externality problem through internalizing all or most of the benefits of the law-suit and, thus, leading to socially optimal private enforcement.

At the same moment, not only positive but also negative external effects may be present here; if group members sue on an individual basis and the defendant wins against the first plaintiff, this may have a negative impact on subsequent plaintiffs.

${ }^{24}$ Ulen (2011: 266). 
Although the judgment given in the case of one of the group members has no res judicata effect in actions brought by other group members, the judgment in the first case may have precedential value or at least persuasive authority. Hence, the defendant may find it rational to invest much more in winning the early cases, because winning in these proceedings may discourage subsequent litigation. ${ }^{25}$

Likewise, collective actions may be cost-effective also for courts. Economies of scale are present here too. Of course, it is to be noted that if individual litigation would not occur due to the above hurdles and inconveniences, collective litigation may actually entail extra-costs for courts, since it may bring matters before the judiciary that would otherwise not be litigated. Nevertheless, this cost-saving is not due to cost-effectiveness but reveals that collective actions may enable the litigation of claims that would otherwise, due to practical hurdles, not come before the judiciary.

\subsection{Why Are Collective Actions Not Working Spontaneously if They Are Efficient?}

Having demonstrated that collective litigation may be more efficient than individual enforcement, the question emerges: why do group members not organize the group proceedings themselves? European legal systems provide for both substantive and procedural tools that could be used for collective litigation. Group members may establish an entity (a company or association) and assign their claims to this entity. ${ }^{26}$ They may also establish a joinder of parties and sue jointly. ${ }^{27}$

The answer lies primarily in the costs of group organization.

First, these costs may be very high, even prohibitive ${ }^{28}$, in case of small-claims. Furthermore, the traditional legal tools that could be used to organize the group were essentially not tailored to the needs of collective actions, thus increasing the costs of organization. For instance, in case of a joinder of parties, individual group members may have different legal representatives and may make pleadings that contradict each other. A joinder of parties does not "centralize" the group; it simply enables group members to be part of the same law-suit and to sit on the same side.

Second, the costs related to the organization of the group may not be or may not be easily shifted. The "loser pays" principle relates to legal costs, and the concept of legal costs may not be tailored to organizational expenses; hence, group representatives may not expect reimbursement for these. Most European systems provide that the losing party pays the costs of the proceedings; however, the expenses related to the organization of the group emerge prior to the proceedings and, hence, their status,

\footnotetext{
${ }^{25}$ Ulen (2011: 189).

${ }^{26}$ Nagy (2011: 16).

${ }^{27} \mathrm{Nagy}(2011: 163)$.

${ }^{28}$ Ulen (2011: 191, 2012: 79).
} 
in this system, is dubious. The group's organizer (representative) may not expect a reasonable return on his expenses, as within the group he may enforce only his claim. ${ }^{29}$

Third, organizational costs qualify as transaction $\operatorname{costs}^{30}$ : they emerge also in case the organization of the group fails and, hence, the collective action is not launched at all. Since the stake of individual group members is small, they would not invest in organizing the group due to the same reasons they do not engage in individual litigation.

Fourth, even if group organizers had the right to claim reimbursement for the organizational costs, the same risk would be involved here as in case of legal costs: cost-shifting occurs only if the plaintiff wins, while organizational expenses emerge irrespective of the outcome of the collective action.

\subsection{How Could Collective Actions Be Made Work?}

There are different methods, which could be used to tackle the problem of high organizational costs. These either reduce organizational expenses or tackle the risks attached to them.

First, opt-out systems are associated with considerably lower organizational costs. ${ }^{31}$ Organizational costs may be reduced significantly through providing that group members do not have to join the group explicitly to become part of the collective action; it is sufficient if they do not leave the group (opt-out). In this case, essentially, the group does not need to be organized, since power of attorney is conferred on group representatives by the law, albeit some organizational costs may emerge. Empirical evidence shows that, not surprisingly, the rate of participation is much higher in opt-out collective proceedings than in opt-in actions. ${ }^{32}$

Second, organizational costs may be mitigated even if the opt-in system is adopted. Although traditional joinder of parties and assignment of claims have always been available for group litigation, these entail considerable organization and case-

\footnotetext{
${ }^{29}$ Silver (2000: 206-207).

${ }^{30}$ See Footnote 25.

${ }^{31}$ Cf. Delatre (2011: 38) (Submitting that the opt-out collective action would be sufficient "on its own and without further incentives to lead to a substantial increase in the number of victims compensated."); Szalai (2014: 708-709).

${ }^{32}$ See Mulheron (2008) 147-156 (A study of jurisdictions where modern empirical data existed showed that opt-out rates had been between 0.1 and $13 \%$; in respect of jurisdictions where such data was not available, judicial summations indicated an opt-out rate between 0 and $40 \%$. On the other hand, in Europe, the experience indicated that the rate of participation, that is opt-in, was on average less than $1 \%$ in large size collective proceedings, albeit in England and Wales participation rate in group litigation varied considerably, from less than 1\% to almost 100\%.); Delatre (2011: 38) ("It is ( ...) submitted that, in a bundle of similar incentives regarding the cost of the action, damages and legal fees, the opt-out arrangement of a class action invariably includes more participants that the alternate opt-in arrangement, as for equal incentives, the rate of rational apathy of victims will always be higher than the rate of victims who opt-in.”).
} 
management costs. A traditional joinder of parties is far from equal to an opt-in collective action. In case of the former, individual group members retain their rights over their own cases: they may make submissions independently from the rest of the group, even if this thwarts the legal tactics of the group representative. In case of an opt-in collective action, the group representative, though supervised by the court, becomes the master of the case. Furthermore, in the opt-in system, organizational costs may be further mitigated through the simplification of group organization (e.g. simplifying the administrative burdens and formal requirements related to declarations of adherence). ${ }^{33}$

Third, the problem of organizational costs may be mitigated also through an effective cost-shifting mechanism: if extending the "loser pays" principle to organizational costs, successful group representatives would be entitled to claim remuneration for their reasonable organizational expenses.

Fourth, this extension of the notion of "legal costs" would not be sufficient to make collective actions work, because group representatives would still run the risk of not being reimbursed for their organizational efforts in the event they fail to organize the group properly (group members do not authorize them in a sufficient number in an opt-in system) or the probability of plaintiff success is less than $100 \%$ (which is normally the case). Individual litigation involves two parties (i.e. the plaintiff and the defendant), and when the plaintiff considers whether to sue or not to sue (that being the question), he obviously takes into account the income accruing to him if the claim is successfully enforced. Collective litigation involves a third actor as well: the group representative, who has to draw his own individual balance of whether to sue or not to sue; however, the group representative may not expect any income (or only a small income, if he is also a group member) from the claims enforced. The individual plaintiff may regard it reasonable to take the risk of not being reimbursed for his legal costs and of being liable for the legal costs of the defendant, because he knows that if he wins, he will get what he sues for. On the other hand, the group representative has no individual stake in the claim or his claim as a group member is incomparably smaller than the costs and risks he assumes in the interest of the group. The "loser pays" rule and the inclusion of the organizational costs in its scope imply that the group representative may be reimbursed for his expenses; however, these do not imply that he will be reimbursed.

Therefore, it is not economically rational for the group representative to engage in group organization in the absence of an appropriate risk premium, which-as a general principle-is not afforded to him in Europe. ${ }^{34}$ While group representatives

\footnotetext{
${ }^{33}$ For a discussion on how complicated it may be to handle a bulk of complaints, see Patetta (2010). ${ }^{34}$ See Hodges (2010: 373) ("In simple terms, a judicial collective damages procedure will only be effective if there exist both an aggregating procedure and liberal financial rules, such that parties (or more likely their lawyers) will have sufficient economic incentives to find it attractive. Ironically, a collective judicial procedure without attractive financial returns for intermediaries will not deliver the policy objectives, but as the financial returns increase, so does the risk of abuse, and adverse consequences become inevitable.”); Cf. Leskinen (2011: 112) (“[T]he possibility of large contingency fees provides incentives to lawyers to bring damages actions and is an essential prerequisite of the functioning of the class action mechanism, in particular, when the individual claims are small").
} 
may have non-economic interests in organizing the group (as civil organizations usually have), economically speaking, the group representative's expected income and expected costs cannot be equilibrated in the absence of an appropriate risk premium.

An alternative solution could be if group members contributed to the organizational costs through paying a fee when joining the group (member contributions). Nonetheless, this solution seems to be both legally unfeasible in opt-out collective proceedings and economically inefficient. First, opt-out collective proceedings may raise constitutional concerns in Europe because they establish power of attorney without authorization. ${ }^{35}$ The main argument against these concerns is that the optout mechanism is justified, because it confers solely advantages on group members ${ }^{36}$ : if the group representative wins, group members receive redress, if he fails, group members do not have to pay anything. ${ }^{37}$ This argument would be lost and constitutional concerns would emerge if group members were held liable for the costs of an action they did not expressly consent to. Second, demanding a contribution from members would be inefficient because it would place the litigation risk on the less informed party. Theoretically, the risk of litigation may be placed either on the group representative or on group members. Group representatives are in the best position to assess the probable outcomes and the risks of the proceedings; hence, it is reasonable to place the risk of litigation on them, compensating them for this hazard through an appropriate risk premium.

The above reasoning holds true also for traditional legal costs. Under the general principle, group members should advance their legal costs and should reimburse the defendant for his legal costs if he wins. Alternatively, at least as to opt-out proceedings, the same constitutional and economic arguments may be applied here as in case of organizational costs. Cost-bearing in case of power of attorney without authorization (that is, opt-out collective actions) may raise constitutional concerns; furthermore, the group representative is in the best position to assess the potential risks attached to litigation, thus, it is more efficient to place this risk on the group representative and to provide him with an appropriate risk premium.

In summary, in order to make collective actions workable, measures are to be taken in two directions. Organizational costs should be lessened and the risk of not being reimbursed for the legal costs and of being held liable for the legal costs of the defendant should be tackled through an adequate risk premium.

\footnotetext{
${ }^{35}$ See Leskinen (2011: 87). For France, see e.g. Conseil Constitutionnel Decision No. 89-257DC, 25 July 1989 (Fr.), reproduced in Magnier and Alleweldt (2008) For Hungary, see e.g. Hungarian Constitutional Court's decisions in Alkotmánybíróság (AB) (Constitutional Court) 4 January 1994, 1/1994. (I. 7.); Alkotmánybíróság (AB) (Constitutional Court) 17 April 1990, 8/1990. (IV. 23.).

${ }^{36}$ See Stuyck (2009: 491), Ioannidou (2011: 79-80).

${ }^{37}$ On the argument that collective proceedings improve access to justice, see Ioannidou (2011: 71-73).
} 


\subsection{Summary}

This chapter described the hurdles that may prevent the individual enforcement of small claims and lead to suboptimal enforcement. It was demonstrated that collective litigation is more efficient in several ways than individual enforcement, and in numerous cases it is the only feasible enforcement mechanism. Given that they generate economies of scale and tackle the problem of positive externalities, collective actions may be a reasonable possibility also in cases where the costs of individual action are prohibitively high.

Having shown that in certain cases collective litigation is more efficient, it was asserted that the absence of the spontaneous emergence of collective actions is chiefly due to the costs of group organization, which qualify as transaction costs and normally cannot be shifted onto the losing defendant. Since organizational costs are crucially important, the regulation should primarily address this issue.

Organizational costs could be considerably lessened with the introduction of the opt-out system. In the opt-in system, the problem of organizational costs could be mitigated through the simplification of group organization (e.g. simplifying the administrative burdens and formal requirements related to declarations of adherence). Irrespective of whether an opt-out or an opt-in system is chosen, organizational costs should be included in the scope of the "loser pays" cost-shifting rule (the losing defendant should be obliged to reimburse the group representative not only for legal costs but also for organizational costs).

For the group representative, it is economically rational to engage in group organization only in exchange for an appropriate risk premium, which is not afforded under the general principles of civil procedure in Europe. Economically speaking, the group representative's expected income and expected costs cannot be equilibrated in the absence of an appropriate risk premium.

\section{References}

Azar-Baud MJ (2012) La nature juridique des actions collectives en droit de la consommation. Revue européenne de droit de la consommation 1:3-28

Bone R (2003) Civil procedure: the economics of civil procedure. Foundation Press

Bosters Th (2017) Collective redress and private international law in the EU. TMC Asser Press, The Hague

Delatre JG (2011) Beyond the White Paper: rethinking the Commission's Proposal on Private Antitrust Litigation. Competition Law Review 8(1):29-58

European Union Agency for Fundamental Rights and Council of Europe (2016) Handbook on European law relating to access to justice. http://fra.europa.eu/en/publication/2016/handbookeuropean-law-relating-access-justice. Accessed on 20 April 2019 
Geiger C (2015) Kollektiver Rechtsschutz im Zivilprozess: Die Gruppenklage zur Durchsetzung von Massenschäden und ihre Auswirkungen. Mohr Siebeck, Tübingen

Gilles M, Friedman G (2006) Exploding the class action agency costs myth: the social utility of entrepreneurial lawyers. University of Pennsylvania Law Review 155:103-164

Hodges Ch (2008) The reform of class and representative actions in European Legal Systems. Hart Publishing, Oxford

Hodges C (2010) Collective redress in Europe: the new model. Civil Justice Quart 29(3):370-395

Ioannidou M (2011) Enhancing the consumers' role in EU private competition law enforcement: a normative and practical approach. Competition Law Rev 8(1):59-85

Juska Z (2014) Obstacles in European competition law enforcement: a potential solution from collective redress. Eur J Legal Stud 7(1):114-139

Lange S (2011) Das begrenzte Gruppenverfahren: Konzeption eines Verfahrens zur Bewältigung von Großschäden auf der Basis des Kapitalanleger-Musterverfahrensgesetzes. Mohr Siebeck, Tübingen

Leskinen C (2011) Collective actions: rethinking funding and national cost rules. Competition Law Rev 8(1):87-121

Magnier V, Alleweldt R (2008) Country report: France. In: Evaluation of the effectiveness and efficiency of collective redress mechanisms in the European Union. Civic Consulting \& Oxford Economics

Mulheron R (2008) Reform of collective redress in England and Wales: a perspective of need. Civil Justice Council. https://www.judiciary.uk/wp-content/uploads/JCO/Documents/CJC/ Publications/Other\%2Bpapers/reform-of-collective-redress.pdf. Accessed 20 April 2019

Mulheron R (2014) The class action in common law legal systems: a comparative perspective. Oxford University Press, Oxford

Nagy CI (2011) A csoportos igényérvényesítés gazdaságtana és lehetôségei a magyar jogban. Jogtudományi Közlöny 66(3):163-174

Nagy CI (2012) Commitments as surrogates of civil redress in competition law: the Hungarian perspective. Eur Competition Law Rev 33(11):531-536

Nagy CI (2013) Comparative collective redress from a law and economics perspective: without risk there is no reward! Columbia J Eur Law 19(3):469-498

Neumann K-A, Magnusson LW (2011) Pour une class-action européenne dans le droit de la concurrence. Revue québécoise de droit international 24(2):149-181

Patetta G (2010) Opportunité du choix de l'opt-in/opt-out - le point de vue de l'UFC - Que choisir, l'action de collective ou action de groupe - se préparer à son introduction en droit français et en droit belge. Larcier

Silver C (2000) Class actions-representative proceedings. In: Encyclopedia of law and economics, vol 5. Edward Elgar Publishing, Cheltenham

Stuyck J (2009) Class actions in Europe? To opt-in or to opt-out, that is the question. Eur Bus Law Rev 20(4):483-505

Szalai Á (2014) Kollektív keresetek szabályozási kérdései - joggazdaságtani elemzés. Magyar Jog 61(12):706-712

Ulen TS (2011) An introduction to the law and economics of class action litigation. Eur J Law Econ $32: 185-203$

Ulen TS (2012) The Economics of Class Action Litigation. In: Backhaus G, Cassone A, Ramello GB (eds) The law and economics of class actions in Europe: lessons from America. Edward Elgar, Cheltenham, pp 75-98

Vanikiotisa MT (2014) Private antitrust enforcement and tentative steps toward collective redress in Europe and the United Kingdom. Fordham Int Law J 37:1639-1681 
Wagner G (2009) Litigation costs and their recovery: the German experience. Civil Justice Quart 28(3):367-388

Wagner G (2011) Collective redress-categories of loss and legislative options. Law Quart Rev 127(1):55-82

Wrbka S, van Uytsel S, Siems MM (2012) Access to justice and collective actions: "Florence" and beyond. In: Wrbka S, van Uytsel S, Siems MM (eds) Collective actions: enhancing access to justice and reconciling multilayer interests?. Cambridge University Press, Cambridge, pp 1-22

Open Access This chapter is licensed under the terms of the Creative Commons Attribution 4.0 International License (http://creativecommons.org/licenses/by/4.0/), which permits use, sharing, adaptation, distribution and reproduction in any medium or format, as long as you give appropriate credit to the original author(s) and the source, provide a link to the Creative Commons license and indicate if changes were made.

The images or other third party material in this chapter are included in the chapter's Creative Commons license, unless indicated otherwise in a credit line to the material. If material is not included in the chapter's Creative Commons license and your intended use is not permitted by statutory regulation or exceeds the permitted use, you will need to obtain permission directly from the copyright holder.

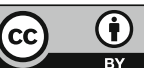

